\title{
Fragmented Production in East Asia: What are Their Implications for the Sino-U.S. Trade
}

\author{
Feiting Lin* \\ Department of economics, Minjiang University, China \\ *Corresponding author: feitinglin@163.com
}

\begin{abstract}
Fragmented production means organization of production in which different stages of production are divided among different suppliers that are located in different countries. East Asia is one of the most important manufacturing centers in the world, China imports components from other East Asian economies for processing and then exports to the United States. The volume of export from China to the United States increase in traditional international trade statistics. Therefore, the solution of Sino-U.S. trade imbalance should pay attention to the relationship between the United States, China, and other East Asian economies.
\end{abstract}

Key words. Fragmented Production; East Asia; Sino-U.S. Trade; Other East Asian Economies; Replace Trade Imbalance;

\section{Introduction}

Since the 1990s, with the international division of labor deepened and refined, fragmented production has emerged. Fragmented production means organization of production in which different stages of production are divided among different suppliers that are located in different countries. Now products traded between firms in different countries are components instead of final products. Most of the final products have been sold to outside the region in which fragmented production happens. East Asia is one of the most important manufacturing centers in the world, and the final products are mainly exported to Europe and the USA. Therefore, the study of fragmentation focus on East Asian countries, this kind of fragmentation is an important part of contemporary globalization. This kind of new international division of labor has some similar interpretation, such as vertical specialization 、Intra-product specialization 、international division of production, localization, outsourcing, etc. However, compared with other explanations, fragmented production focuses on the division of labor among different countries, mainly used for the analysis of East Asian production. As fragmented production has grown, so too has the potential for gross flows of trade to mislead.

\section{The Current Situation of Sino-U.S. Trade Imbalance}

Since the 1990s, Sino-U.S. trade is booming. According to U.S. Department of Commerce Bureau of Economic Analysis, the United States and China bilateral goods import and export volume topped 600.82 billion dollars in 2015, increased 1.3\%. The United States exported to China 116.70 billion dollars in goods, down $6.1 \%$, imported 481.12 billion dollars, up $3.2 \%$, Sino-U.S. trade imbalance up to 367.42 billion dollars in goods, increased $6.6 \%$. Sino-U.S. trade imbalance accounting for $48.18 \%$ of the total U.S. trade deficit in goods, which is the largest source of deficit countries in the world.

\subsection{Trade surplus in goods coexists with the trade deficit in services in Sino-U.S. trade imbalance.}

The United States is the largest exporter countries in services, also is the largest services surplus countries. In Sino-U.S. trade imbalance, Trade surplus in goods coexists with trade deficit in services. As shown in Table 1, the United States and China bilateral import and export in services is increasing year by year ${ }^{\text {ii }}$, and the volume of U. S. export to China in services is also increasing rapidly. The United States has stable earnings from Sino-U.S. service trade. The Sino-U.S. trade deficit in services up to 333.36 billion dollars in 2015, increased 9.24\%. From the view of proportion, The Sino-U.S. trade deficit in services accounting for $0.19 \%$ of the Sino-U.S. trade surplus in goods in 2006, but accounting for $9.07 \%$ in 2015, the proportion increased year by year. Compared with the Sino-U.S. trade volume in goods, the volume of trade in services is relatively small, which can't reverse the overall Sino-U.S. trade surplus. In Sino-U.S. trade imbalance, trade surplus in goods coexists with trade deficit in services, and the volume of surplus and deficit both are increasing year by year. Sino-U.S. trade surplus in goods in the main reason of Sino-U.S. trade imbalance. 
Table 1 Balance on goods and services in Sino-U.S. trade Units: Billion Dollars

\begin{tabular}{|l|c|c|c|c|c|c|c|c|c|c|}
\hline \multicolumn{1}{|c|}{ YEAR } & 2006 & 2007 & 2008 & 2009 & 2010 & 2011 & 2012 & 2013 & 2014 & 2015 \\
\hline Exports of services & 10.57 & 13.13 & 15.85 & 17.06 & 22.5 & 28.44 & 33.04 & 37.5 & 44.50 & 48.44 \\
\hline Imports of services & 10.14 & 11.8 & 10.92 & 9.56 & 10.61 & 11.78 & 13.04 & 13.9 & 14.0 & 15.11 \\
\hline Balance on goods & -234.4 & -258.7 & -268.2 & -227.2 & -273.1 & -295.2 & -314.9 & -318.8 & -345.0 & -367.4 \\
\hline Balance on services & 0.43 & 1.34 & 4.92 & 7.5 & 11.89 & 16.65 & 20.0 & 23.62 & 30.52 & 33.34 \\
\hline
\end{tabular}

Source: U.S. Department of Commerce, Bureau of Economic Analysis

http://www.bea.gov/international/factsheet/factsheet.cfm?Area=650

*Due to the impact of American subprime mortgage crisis and international financial crisis, the service volume U. S. import from China decreased in 2008 and 2009.

\subsection{The Sino-U.S. trade surplus in goods transferred commodity structure from labor-intensive products to capital and technology-intensive products.}

Analyzed from the commodity description of Sino-U.S. trade, there is a big changed between trade imbalance in goods. According to Standard International Trade Classification (SITC) of the United Nations, classify the exports and imports to ten categories reflected raw materials s semi-finished products and finished products. As shown in Table 2, the top-3 categories of Sino-U.S. trade surplus in goods comes from categories 6、7、8, which concentrated in the field of industrial finished products and semi-finished products. The category of Sino-U.S. trade deficit in goods mainly come from category 2, which concentrated in the field of raw materials. Then analyzed from the commodity description of Sino-U.S. trade imbalance, SITC8 including furniture、 clothing、 footwear and small goods, is Labor intensive products. The proportion of SITC6 in Sino-U.S. trade imbalance in goods is decreased year by year, accounting for $73.5 \%$ in 1996 , which is the main commodity source of Sino-U.S. trade imbalance in goods. down to $59.5 \%$ in $2001,42.8 \%$ in $2006,39.8 \%$ in $2012,38.6 \%$ in 2015. SITC7 including electronic storage, radio transmitter, recorder and digital accessories, excavator and so on. The proportion of SITC7 in Sino-U.S. trade imbalance in goods is increased year by year, accounting for $21.3 \%$ in $1996,29.7 \%$ in $2001,46 \%$ in 2006 , up to 57.6 in $2012,53.7 \%$ in 2015 , which is the main commodity source of Sino-U.S. trade imbalance in goods. The Sino-U.S. trade surplus in goods are transferred commodity structure from labor-intensive products to capital and technology-intensive products. Machinery and transport equipment substituted for Miscellaneous manufactured articles, which has been the main commodity source of Sino-U.S. trade imbalance in goods. Source: U.S. Census Bureau. http://censtats.census.gov/cgi-bin/sitc/sitcCty.pl

Table2 The commodity description of Sino-U.S. trade imbalance Units: Billion Dollars

\begin{tabular}{|c|l|c|c|c|c|c|}
\hline SITC & \multicolumn{1}{|c|}{ Dec. } & 1996 & 2001 & 2006 & 2012 & 2015 \\
\hline 0 & Food and live animals & 1.2 & -6.3 & -21.6 & 4.8 & 20.2 \\
\hline 1 & Beverages and tobacco & -0.1 & -0.3 & 0.4 & 1.5 & 2.4 \\
\hline 2 & Crude materials, inedible, except fuels & 15.1 & 25.5 & 122.4 & 334.8 & 221.4 \\
\hline 3 & Mineral fuels, lubricants and related materials & -4.5 & -2.9 & -9.6 & 22.2 & 17.6 \\
\hline 4 & Animal and vegetable oils, fats and waxes & 1.1 & 0.1 & 0.5 & 2.9 & -0.1 \\
\hline 5 & Chemicals and related products, n.e.s. & 6.9 & 1.5 & 0.0 & -9.2 & -20.5 \\
\hline 6 & Manufactured goods classified chiefly by material & -37.7 & -97.0 & -325.0 & -401.4 & -483.1 \\
\hline 7 & Machinery and transport equipment & -84.2 & -246.6 & -1076.0 & -1814.3 & -1964.9 \\
\hline 8 & Miscellaneous manufactured articles & -290.3 & -494.2 & -1002.1 & -1255.2 & -1411.5 \\
\hline 9 & $\begin{array}{l}\text { Commodities and transactions not classified } \\
\end{array}$ & -2.7 & -10.2 & -29.9 & -36.6 & -38.5 \\
\hline & total & -395.2 & -830.5 & -2341.0 & -3150.5 & -3656.9 \\
\hline
\end{tabular}

\section{The impact of fragmented production in East Asia on the Sino-U.S. trade imbalance}

Fragmented production theory focus on production network in East Asia, emphasize the disassembly production process according to factor endowment in the East Asia. products traded in different countries are components instead of final products. Now products traded between firms in different countries are components instead of final products. most of the final products are sold to Europe and the USA. Therefore, this paper focus on components and trade flows to analyze the impact of fragmented production on Sino-U.S. trade imbalance.

\subsection{Analyzed from commodity structure, China undertake terminal processing and assembly process in the East Asia fragmented production network.}

According to the second part of this paper, the analysis of the current situation of Sino-U.S. trade imbalance, can be concluded that Sino-U.S. trade surplus of goods has transferred from labor-intensive products to capital and 
technology-intensive products. According to factor endowment theory, The United States is capital and technology abundant, China is labor abundant, so Sino-U.S. trade should be exported labor-intensive products from China, exported capital and technology-intensive products from the United States, and Sino US trade surplus in goods should focus on labor-intensive products, while the actual Sino-U.S. trade surplus in goods is contrary to the factor endowments of the two countries.

Analyzed from the perspective of fragmented production in East Asia, East Asian economies according to the advantages of natural resources to disassembled the commodity process, Japan, South Korea, and other East Asian economies have the advantage in producing machinery and transport equipment, China with the advantage of labor resources to participated in the fragmentation, such as assembly processing.

Take the hard disk drive production for example, four biggest hard disk drive manufacturers are Seagate and WD from United States、Toshiba from Japan、Samsung from South Korea, most of the components used by them are from East Asia. As shown in Figure 1, substrate suppliers all come from Japan, such as Furukawa Electric and Kobe Steel supply aluminum substrate, Hoya supply glass substrate. Then the biggest disc's supplier is Showa Denko from Japan Ishida, and Seagate and WD. The electric motor market monopolized by Nidec from Japan. The manufacturers of Magnetic read-write head also come from Japan, such as TDK、Showa Denko、Fuji Electric and so on.

Because of the labor cost in Japan is higher, so the components of hard disk drive suppliers choose other place in Asian area to organize production to reduce the costs through the division of labor in fragmented production. Then the hard disk drive manufacturers use the same way to organize production. Therefore, with the fragmented production establishing in East Asia, China has become the capital and technology intensive products export country because of its low labor cost in processing.

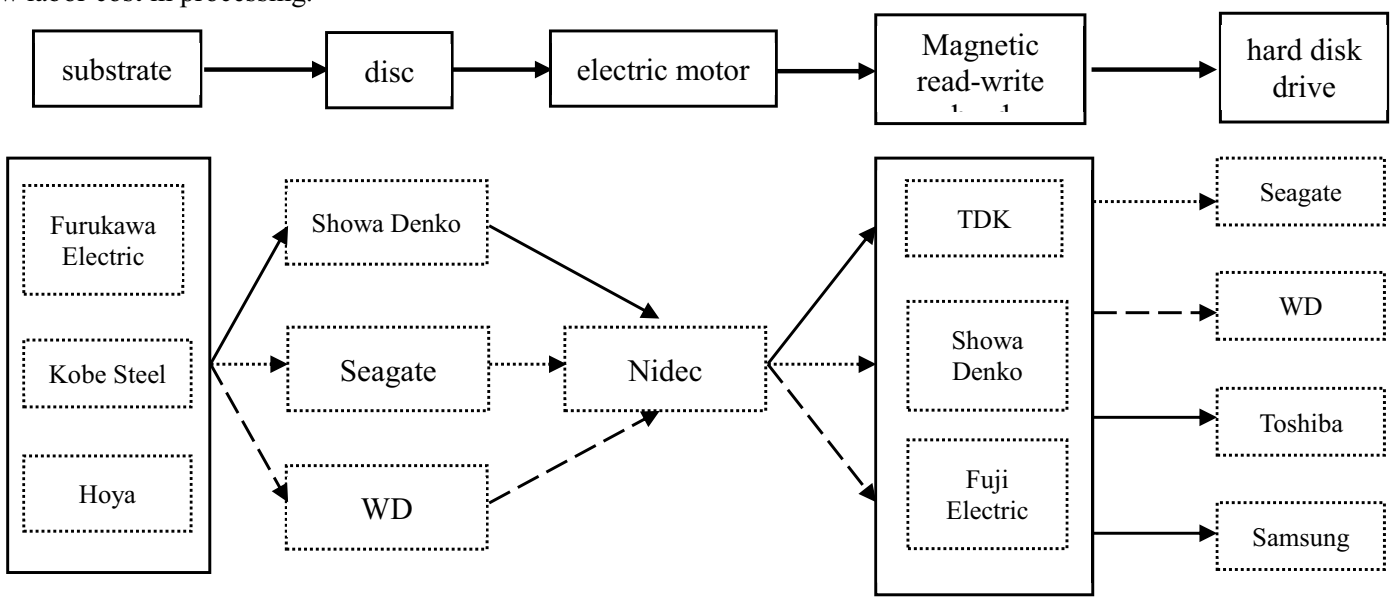

$$
\begin{aligned}
& \rightarrow \ldots+. . . \rightarrow \text { The trend of components used by Seagate } \\
& -\rightarrow \rightarrow \text { The trend of components used by WD }
\end{aligned}
$$

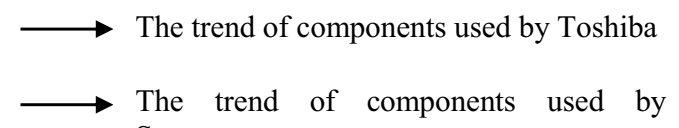

Figure 1:

The trend of components used by hard disk drive

Source: organize and summarize by author.

*Due to the Diaoyu Islands issue, the trade between China and Japan decreased in 2012, China reduces imports from Japan.

\subsection{Analyzed from the flow of trade, the trend changes between China's imports from East Asia and the United States exports to China are the same}

Fragmented production theory emphasized that most of the final products are sold outside the region. Analyzed from the flow of trade, if the trend changes between China's imports from East Asia and the United States exports to China are the same, it's can be considered that China undertakes assembly processing of Capital and technology intensive products to substitute for other East Asian economies to export to the United states.

Take SITC7 (Machinery and transport equipment) for example, as shown in figure 2, the changes between China export to American and China import from Japan, South Korea and ASEAN move in the same direction ${ }^{\text {iii }}$. Because of the impact of the international financial crisis in 2009, China reduces the imports from Japan, South Korea and ASEAN, then China exports to the U.S. also decreased. Therefore, in the traditional international trade statistics method, they just count 
the final product export and import, the assembly products from East Asia in China is all count for China export to American, ignoring the triangle trade relationship between the United States, East Asia and China, resulting in the exaggerated volume between China and American, twisted the Sino-U.S. trade imbalance.

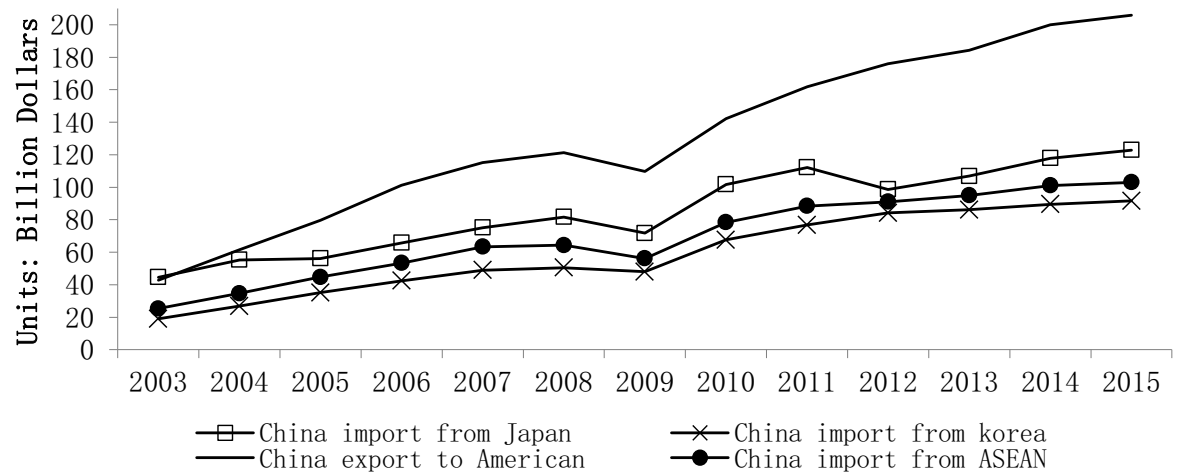

Figure 2: The volume of SITC7 that China export to American and China import from Japan、Korea and ASEAN

Source: United Nations Commodity Trade Statistics Database. http://comtrade.un.org/db/dqQuickQuery.aspx

*The statistics of other East Asia's economies in here only include: Japan, Korea, Taiwan, ASEAN.

\subsection{Fragmented production in East Asia exaggerated the Sino-U.S. trade imbalance}

East Asia is one of the most important manufacturing centers in the world, if take countries in East Asian as a whole, the United States is continued to be in deficit. According to the U.S. Department of Commerce statistics, China replace Japan as the largest source of trade deficit in 2000, is the second largest trading partner、the third biggest export market and the biggest source of imports with the United States. According to Chinese customs statistics, the trade deficit between China and other East Asian economies are coexisted with Sino-U.S. trade surplus. As shown in figure 3, With the increase of Sino-U.S. trade imbalance, the trade deficit between China and other East Asia's economics ${ }^{\text {iv }}$ is also increased, the trend of change in volume are nearly the same. Therefore, China participate in the fragmented production in East Asia, replaced the other economies in East Asian to export to American, exaggerated the Sino-U.S. trade imbalance.

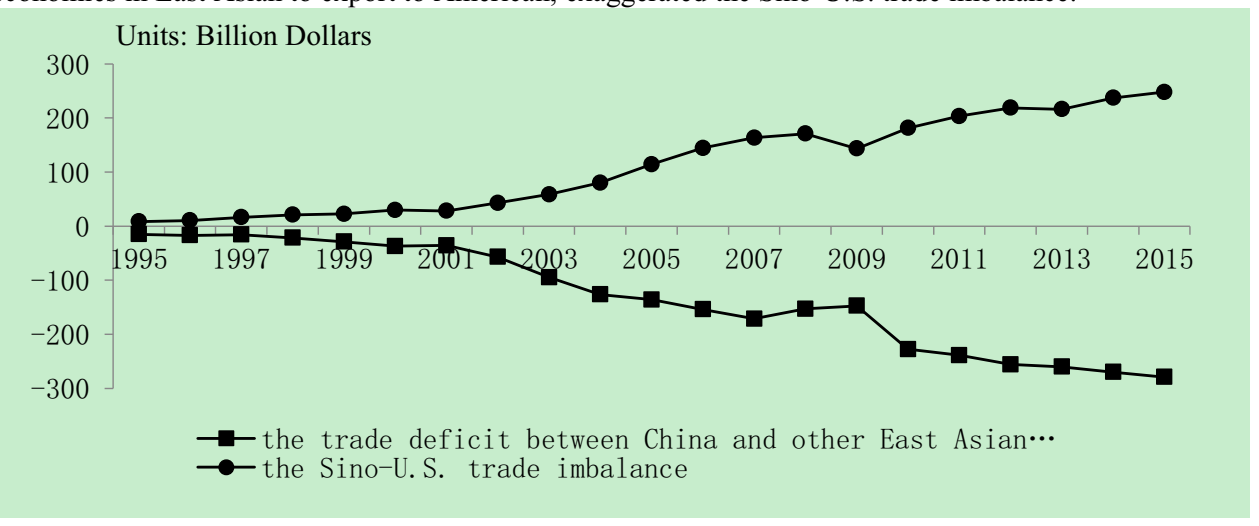

Figure 3: The Sino-U.S. trade imbalance and the trade deficit between China and other East Asian economies

Source: Statistical Yearbook of China

\section{Conclusion}

With fragmented production in East Asia, ASEAN and other East Asian economies transfer the labor-intensive part of production to Chinese, by using the low labor costs in China to process. Those economies in East Asian was also the mainly source of imports from the United States, so when they transferred the part of fragmented production to China, they also transferred their trade surplus with the United States to China with the traditional international trade statistics by using final product for accounting standard. Because of China participate in the fragmented production in East Asia by using labor endowment, at a low value-added chain, profit is very few, while the United States import from other East Asian economies due to lower labor costs in China is cheaper than before, so American consumers are getting more 
benefit. Fragmented production in East Asia ignored the triangle trade relationship between the United States, East Asia and China, resulting in the exaggerated volume between China and the United States, twisted the Sino-U.S. trade imbalance. The Sino-US trade imbalance does not reflect the gains, so the development of bilateral economic and trade relations should pay attention to the relationship between the United States, China and other East Asian economies instead of the volume of Sino-U.S. trade imbalance, asked China to open the market, to reform RMB exchange rate, to introduce trade protection can't fundamentally solve the problem of Sino-U.S. trade imbalance.

\subsection{Correctly deal with the impact of exchange rate on Sino-US trade imbalance, and steadily promote the reform of the RMB exchange rate}

The fundamental cause of the Sino-U.S. trade imbalance is China substitute for other East Asian economies to export to American in the fragmented production network in East Asia, whether appreciation or devaluation of the RMB has no effect to solve the Sino-U.S. trade imbalance. Correctly deal with the impact of exchange rate on Sino-US trade imbalance, China government should insist the independent exchange rate policy, to plan, step by step to steadily promote the reform of the RMB exchange rate.

\subsection{Taking technological innovation as the goal, by participating in the process of East Asia fragmented production to upgrade the domestic industrial structure}

Other East Asian economies transfer labor-intensive part of capital and technology intensive products to China not only because of labor endowment, but also because China enterprises lags behind other countries in R\&D, can only in assembly process in the industrial-chain division. Therefore, for the purpose of technological innovation, China involved in fragmented production in East Asia actively, should learn the advanced experience from other East Asian economies to upgrade domestic industrial structure at the same time, to promote economic growth turn to high value-added capital and technology intensive production.

\subsection{Implement the "going out" overseas investment strategy actively, to achieve product diversification and country of origin diversification}

The advantage of China's participation in fragmented production is the endowment of labor factors in East Asia. With economic growth, per capita income grows, the cost of labor also grows, China enterprises should implement the "going out" overseas investment strategy actively, master technique from other developed countries through fragmented production, then transfer labor-intensive part to other developing economies to relief trade friction, which to realize the sustainable growth of China's economy.

\section{Acknowledgements}

This research was supported by the Education Department of Fujian Province (project number: JAS160422) and Minjiang University (project number: YSY13008).

\section{References}

1. [1] Jianjiang Liu, Xizhen Yang. Study on the trade interests of Sino US trade imbalance from the perspective of intra product specialization. international trade issue. 8(2011)68-80.

2. [2] Liwei An, Yeqing Ma. Journal of international fragmentation of production and the Sino US trade imbalance. Nanjing University. 3(2012)31-39.

3. [3] Jihong Lin, Jing Meng. The influence of international vertical specialization on Sino US trade surplus. world economy research. 11 (2012)38-43.

4. [4] Koopman, R., Z. Wang \& S.J. wei, How Much of Chinese Exports is Really Made in China? Assessing Domestic Value-Added When Processing Trade is Pervasive[EB/OL]. NBER Working Paper 14109.

5. [5] Athukorala, P. \& N. Yamashita, Global Production Sharing and Sino-US Trade Relations. China \& World Economy. 3(2009)39-56.

6. [6] Fung, K.C. and L.J. Lau. The China-United States Bilateral Trade Balances: How Big is it Really?. Pacific Economic Review. 3 (1998)33-47.

7. [7] Bart Los, Erik Dietzenbacher, Robert Stehrer, Marcel Timmer and Gaaitzen de Vries. Trade Performance in Internationally Fragmented Production Networks: Concepts and Measures. WIOD Working Paper 11.

8. [8] Blyde J, Molina D. Logistic infrastructure and the international location of fragmented production. Journal of International Economics. 95(2015)319-332. 
9. [9] Mattoo A, Wang Zhi, Wei S Jin. Measuring trade in value added when production is fragmented across countries: An overview. Trade in Value Added. 25(2013).

10. [10] Bai Y, Liu Y. Causes and Countermeasures for Sino-US Trade Imbalance: From the Perspective of International Trade. Journal of Chinese Economics. 2(2014)1. 